\title{
Pengaruh Efektivitas Penerapan SIA, Pemanfaatan TI, Kesesuaian Tugas, dan Keahlian Pemakai Komputer pada Kinerja Karyawan
}

\author{
Ni Made Fikiyaya Anjani Dewantari ${ }^{1}$ \\ I Made Pande Dwiana Putra ${ }^{2}$ \\ ${ }^{1,2}$ Fakultas Ekonomi dan Bisnis Universitas Udayana (Unud), Bali, Indonesia \\ e-mail: fikiyaya_anjani@yahoo.co.id
}

\begin{abstract}
ABSTRAK
Tujuan penelitian ini yaitu untuk mengetahui pengaruh efektivitas penerapan sistem informasi akuntansi, pemanfataan teknologi informasi, kesesuaian tugas dan keahlian pemakai komputer pada kinerja karyawan. Penelitian ini dilakukan di PT Karya Luhur Permai Denpasar. Berdasarkan hasil penelitian, dinyatakan bahwa efektivitas penerapan sistem informasi akuntansi, pemanfataan teknologi informasi, kesesuaian tugas dan keahlian pemakai komputer berpengaruh positif dan signifikan pada kinerja karyawan. Hal ini berarti semakin tinggi efektivitas penerapan sistem informasi akuntansi, pemanfataan teknologi informasi, kesesuaian tugas dan keahlian pemakai komputer, makan kinerja karyawan akan semakin meningkat. Penelitian ini telah membuktikan bahwa efektivitas penerapan sistem informasi akuntansi, pemanfataan teknologi, kesesuaian tugas dan keahlian pemakai komputer mempunyai pengaruh positif terhadap kinerja karyawan, sehingga sangat mendukung konsep dari TAM, Teori TPC, dan Teori Kontingensi.
\end{abstract}

Kata Kunci : SIA, keahlian pemakai komputer, kinerja karyawan.

\begin{abstract}
The purpose of this study is to determine the effect of the effectiveness of the application of accounting information systems, utilization of information technology, suitability of tasks and computer user expertise on employee performance. This research was conducted at PT Karya Luhur Permai Denpasar. Based on the results of the study, it was stated that the effectiveness of the application of accounting information systems, utilization of information technology, suitability of tasks and computer user expertise had a positive and significant effect on employee performance. This means that the higher the effectiveness of the application of accounting information systems, the use of information technology, the suitability of tasks and expertise of computer users, to eat employee performance will increase. This research has proven that the effectiveness of the application of accounting information systems, the use of technology, the suitability of tasks and computer user expertise has a positive influence on employee performance, so it strongly supports the concepts of TAM, TPC Theory, and Contingency Theory.

Keywords: Accounting information system, computer user expertise, employee performance
\end{abstract}

\section{PENDAHULUAN}

Perkembangan serta kemajuan sistem informasi berbasis teknologi terjadi begitu pesat dan memberikan pengaruh yang sangat signifikan terhadap penerapan sistem informasi akuntansi dalam suatu organisasi. Sistem informasi dapat dimanfaatkan oleh banyak pihak untuk mencapai keunggulan perusahaan 
Ni Made Fikiyaya Anjani Dewantari dan I Made Pande Dwiana Putra. Pengaruh ...

melalui kecepatan, fleksibilitas, integrasi, dan keakuratan informasi yang dihasilkan (Astuti dan Dharmadiaksa, 2014).

Astuti dan Dharmadiaksa (2014) menyatakan bahwa sistem informasi dapat menjadi kriteria dasar untuk mengevaluasi kualitas dan sistem dari informasi yang dihasilkan. Kinerja dapat menjadi tolak ukur dari keberhasilan sebuah sistem. Kinerja yang dimaksud adalah kinerja yang dicapai oleh seseorang selama periode tertentu di dalam melaksanakan tugas secara keseluruhan dibandingkan dengan berbagai kemungkinan, seperti standar hasil kerja, sasaran atau kriteria atau target yang telah ditentukan dan disepakati bersama. Kinerja karyawan sangatlah perlu, sebab dengan kinerja ini akan diketahui seberapa jauh kemampuan pegawai dalam melaksanakan tugas yang dibebankan kepadanya. Perlu adanya penentuan kriteria kinerja yang jelas dan terukur serta ditetapkan secara bersama-sama yang dijadikan sebagai acuan. Agar kinerja karyawan di perusahaan dapat dioptimalkan, maka keefektifan sistem informasi sebagai sarana yang memfasilitasi harus terus dikembangkan.

Dari keberhasilan sebuah sistem didapatkan berbagai masalah yang berkaitan dengan kinerja karyawan muncul sebagai dampak adanya penyesuaian atas sistem informasi. Contoh fenomena yang terjadi berkaitan dengan kinerja karyawan yang buruk terjadi pada PT Telkom (Persero). Terjadi kesalahan dalam proses input data pelanggan yang dilakukan oleh karyawan Telkom, sehingga pelanggan mengalami pembengkakan tagihan. Pelanggan melaporkan bahwa adanya kerusakan pada jaringan telepon selamat 4 hari pada pukul 12.15 dan laporan tersebut baru dilaporkan beberapa harikemudian oleh sang pelanggan. 
Kemudian pelanggan melaporkan ulang kembali, namun teknisi tetap tidak datang dan tidak menghubungi pelanggan. Pelayanan telkom menjanjikan bahwa akan segera menindak lanjuti pengaduan pelanggan dan akan memberikan kompensasi apabila dalam 1x24 jam belum terdapat tindakan dari pihak teknisi telkom, lalu hal tersebut ternyata sudah lewat dari waktu yang telah dijanjikan. Hal ini terjadi karena keluhan pelanggan tersebut tidak dicatat oleh karyawan ke dalam sistem informasi yang tersedia di perusahaan, sehingga mengakibatkan hal tersebut tidak dapat segera ditangani oleh para teknisi. Kerugian dari hal tersebut adalah bahwa pelanggan tidak dapat menggunakan fasilitas yang seharusnya menjadi hak pelanggan tersebut (http://www.kompas.com, dalam Ocktotawwa, 2015).

Fenomena selanjutnya terjadi pada PT. Jamsostek. Badan Pemeriksa Keuangan (BPK) menyatakan PT. Jamsostek (Persero) belum efektif memberikan perlindungan dengan membayarkan manfaat program Jaminan Hari Tua (JHT). BPK juga menemukan belum efektifnya registrasi kepesertaan dalam sistem informasi PT. Jamsostek. BPK meminta agar sistem teknologi informasi yang mendukung keandalan data harus dibenahi. Terkait sistem data, Jamsostek akan menggunakan sistem elektronik baik untuk proses registrasi, pembayaran, dan klaim untuk meningkatkan pelayanan konsumen (http:www.tempo.com, dalam Ocktotawwa, 2015).

Berdasarkan fenomena yang ada, dapat dikatakan bahwa penerapan sistem informasi masih memperoleh hasil yang kurang efektif bagi peningkatan kinerja karyawan sehingga menimbulkan berbagai kerugian bagi perusahaan. Kinerja karyawan sangat dipengaruhi oleh sistem informasi yang nantinya akan 
Ni Made Fikiyaya Anjani Dewantari dan I Made Pande Dwiana Putra. Pengaruh ...

mendukung kinerja perusahaan dan tujuan perusahaan. Kinerja karyawan mempunyai peran penting dalam sistem informasi sebuah perusahaan.

Sistem informasi yang digunakan bisa dikatakan gagal atau tidak sesuai dengan sistem informasi yang dibutuhkan perusahaan, maka sisem informasi tersebut dapat dikatakan memberi efek negatif kepada kinerja pegawai. Kinerja suatu perusahaan bermasalah apabila dalam melaksanakan aktivitas bisnisnya perusahaan dan komponen yang ada dalam perusahaan dianggap berjalan lamban dalam mencapai sasaran yang ditetapkan. Salah satu sistem informasi yang digunakan dalam perusahaan adalah sistem informsi akuntansi yang merupakan suatu sumber daya manusia dan modal dalam organisasi yang bertugas menyiapkan informasi keuangan dan juga informasi yang diperoleh dari kegiatan pengumpulan dan pengolahan transaksi (Marlinawati dan Suaryana, 2013). Salehi et al., (2010) menyatakan bahwa sistem informasi akuntansi merupakan sistem yang terdiri dari sub-sub sistem yang digunakan oleh organisasi untuk mengumpulkan, menggolongkan, mengolah, menganalisa, dan mengkomunikasikan informasi keuangan yang nantinya akan dijadikan sebagai salah satu alasan dalam pengambilan keputusan. Ismail dan King (2007) menyatakan bahwa perusahan yang memiliki teknologi informasi adalah perusahaan yang memiliki tingkat keselarasan sistem teknologi informasi yang baik dibandingkan dengan perusahaan yang tidak menggunakan teknologi. Penerapan sistem informasi akuntansi merupakan investasi penting bagi sebuah perusahaan (Raupeliene, 2003). Sistem informasi akuntansi merupakan bagian penting dalam mendukung daya saing serta peningkatan efisiensi organisasi 
melalui penyediaan informasi keuangan maupun akuntansi (Alsarayreh et al., 2011)

Penelitian mengenai pengaruh efektivitas sistem informasi akuntansi pada kinerja karyawan telah dilakukan sebelumnya oleh Astuti (2014) dan Mercika (2015) yang menyatakan bahwa efektivitas sistem informasi akuntansi berpengaruh positif dan signifikan terhadap kinerja karyawan maupun perusahaan. Menurut penelitian yang dilakukan oleh penelitian Urquia et al. (2010), Kharuddin et al. (2010), Kouser et al. (2011), dan (Hidayati (2017) menunjukkan bahwa adanya sistem informasi akuntansi tidak meningkatkan kinerja, profitabilitas, maupun efisiensi operasi. Penelitian Soudani (2012) dan Galang (2014) juga menyatakan bahwa tidak mendukung adanya hubungan yang positif antara sistem informasi akuntansi terhadap kinerja.

Kinerja karyawan dalam menjalankan fungsinya berhubungan dengan kepuasan kerja dan tingkat imbalan yang dipengaruhi oleh keterampilan, kemampuan, dan sifat-sifat individu. Sifat-sifat individu juga mempengaruhi teknologi informasi yang berkembang saat ini dan seiring dengan perkembangan teknologi informasi. Masalah sering muncul ketika teknologi yang diterapkan dalam sistem informasi tidak sesuai atau tidak dimanfaatkan secara maksimal oleh pemakai sistem sehingga penerapan sistem informasi kurang memberikan manfaat atau bahkan tidak bermanfaat sama sekali (Astuti dan Dharmadiaksa, 2014).

Penelitian mengenai pengaruh pemanfaatan teknologi informasi pada kinerja karyawan telah dilakukan sebelumnya oleh Kasandra (2014) dan Wahyuni (2014) yang menunjukan bahwa pemanfaatan teknologi informasi berpengaruh 
Ni Made Fikiyaya Anjani Dewantari dan I Made Pande Dwiana Putra. Pengaruh ...

positif dan signifikan terhadap kinerja individu. Penelitian yang dilakukan oleh Jurnali (2002) dan Jin (2003) mempunyai hasil yang menunjukan bahwa pemanfaatan teknologi informasi tidak mempengaruhi kinerja individual.

Tujuan utama sistem informasi akuntansi dibangun adalah untuk mengolah data akuntansi yang berasal dari berbagai sumber menjadi sebuah informasi akuntansi yang diperlukan oleh seluruh pihak yang menggunakan untuk mengurangi resiko saat mengambil keputusan. Teknologi informasi yang digunakan harus berhubungan dengan tugas-tugas yang dikerjakan oleh pengguna. Adanya penerapan sistem teknologi informasi di dalam perusahaan diharapkan dapat membantu aktivitas perusahaan untuk meningkatkan kinerja.

Meningkatkan sebuah kinerja dapat dilakukan dengan cara mengevaluasi pemakai atas kecocokan tugas dengan teknologi yang artinya hal ini akan berkaitan dengan pencapaian kinerja karyawan yang tinggi. Masalah yang sering muncul adalah ketika karyawan tidak memanfaatkan teknologi yang disediakan dalam membantu penyelesaian tugas secara maksimal, sehingga teknologi kurang memberikan manfaat yang tepat. Evaluasi atas pemakai/pengguna dapat digunakan sebagai alat ukur keberhasilan pelaksanaan kualitas jasa sistem informasi yang dihubungkan dengan kecocokan tugas-tugas dengan teknologi (Marlinawati dan Suaryana, 2013).

Penelitian terdahulu mengenai pengaruh kesesuaian tugas dengan teknologi informasi terhadap kinerja karyawan yang dilakukan oleh Jin, (2003) menunjukan hasil yang negatif, yang berarti adanya ketidaksesuaian tugas-teknologi dimana dalam menyelesaikan pekerjaan, pengguna merasa terhambat dalam mengakses 
data untuk memperoleh data yang akurat dan tepat. Penelitian Rahmawati (2008), Weyai (2012), Marlinawati dan Suaryana (2013) serta Astuti dan Dharmadiaksa, (2014) menemukan hubungan yang positif dan signifikan antara kesesuaian tugas teknologi dengan pemanfaatan sistem informasi dan teknologi informasi.

Penggunaan komputer dalam aktivitas bisnis yang ditunjang dengan tersedianya berbagai software telah menjanjikan bahwa berbagai transaksi akuntansi dalam bisnis penyediaan informasi dapat dilakukan lebih mudah, efektif, dan efisien. Sistem informasi akuntansi dibangun untuk pengguna, maka sistem informasi akuntansi yang dibangun hasilnya harus sesuai dengan kebutuhan pengguna. Para pengguna atau pemakai sistem informasi sebagian besar merupakan orang-orang yang hanya akan menggunakan sistem informasi yang telah dikembangkan seperti operator dan manajer (end user). Para pemakai biasanya hanya terfokus pada pekerjaannya walaupun telah memiliki pengetahuan tentang komputer. Keahlian pemakai dalam menggunakan teknologi komputer harus terus dikembangkan. Semakin ahli pemakai dalam menggunakan komputer akan membantu proses kinerja dalam upaya mencapai tujuan dan sasaran perusahaan. Keahlian pemakai dalam menggunakan komputer akan mendukung keberhasilan dalam upaya peningkatan kinerja. Keahlian pemakai komputer yang dimaksud adalah kemampuan pemakai komputer (user) dalam hal aplikasi komputer (Pratama dan Suardikha, 2013). Jong Min Choe (1996) dan Bailey (1983) menyatakan bahwa baik buruknya kinerja sistem informasi akuntansi dapat diukur dari sisi pemakai (user) dengan membagi kinerja SIA kedalam dua bagian, 
Ni Made Fikiyaya Anjani Dewantari dan I Made Pande Dwiana Putra. Pengaruh ...

yaitu kepuasan pemakai sistem informasi akuntansi dan pemakaian sistem informasi akuntansi.

Penelitian Suyati (2015), Ocktotawwa (2015) serta Pratama dan Suardikha (2013) menemukan bahwa keahlian pemakai komputer berpengaruh positif dan signifikan tehadap kinerja karyawan. Hal ini berarti antara kemampuan dan keberhasilan implementasi sistem informasi berhubungan kuat dalam meningkatkan kinerja karyawan. Menurut Davista (2008) dan Asiyatun (2012) menyatakan bahwa keahlian pemakai dalam menggunakan komputer mempunyai pengaruh yang negatif terhadap kinerja karyawan.

Penelitian ini dilaksanakan pada PT Karya Luhur Permai Denpasar sebagai salah satu retailer yang memiliki cakupan kegiatan yang luas dan kompleks. Seluruh kegiatan pada perusahaan ini telah menggunakan teknologi informasi dan sistem informasi akuntansi. Permasalah yang timbul dari perusahaan ini terletak pada para karyawan yang bekerja khususnya mengenai sistem informasi. Karyawan yang bekerja telah diberikan pelatihan mengenai sistem, namun masih saja terjadi permasalahan dalam penggunaannya, seperti kesulitan penggunaan, sistem yang tidak mudah dimengerti menjadi penghambat karyawan dalam bekerja. Dari hasil pengamatan di lapangan, menurut informasi Manager Gudang masih saja ditemui karyawan bagian administrasi gudang yang melakukan kesalahan dalam melakukan input barang datang, semestinya barang yang datang diinput 12 pcs, tetapi diinput 12 dos. Hal ini berdampak pada tidak akuratnya stock barang, dan juga kelebihan pembayaran ke supplier. Kesalahan lainnya yang juga terjadi, yaitu pada proses koreksi stok barang (stock opname), seharusnya 
barang diinput 1 gross (144 pcs), tetapi pada kenyatannya diinput 1 lusin (12 pcs), sehingga seolah-olah stok barang sedikit, padahal kenyataan barang masih banyak. Kesalahan tersebut berdampak pada proses munculnya surat pesanan, semestinya barang tersebut belum saatnya diorder, tetapi karena kesalahan input stok barang, akhirnya munculah orderan baru, hal ini berdampak pada jumlah persediaan barang yang berlebihan (over stock).

Penelitian ini merupakan replikasi dari penelitian terdahulu yang dilakukan oleh Astuti dan Dharmadiaksa (2014) yang berjudul Pengaruh Efektivitas Penerapan Sistem Informasi Akuntansi, Pemanfaatan Teknologi Informasi dan Kesesuaian Tugas pada Kinerja Karyawan. Penelitian ini dilakukan pada Koperasi Simpan Pinjam di Kabupaten Gianyar Bali. Perbedaan yang terdapat dalam penelitian ini dengan penelitain sebelumnya yaitu adanya penambahan variabel independen dan perbedaan tempat. Penelitian ini memakai empat variabel independen yaitu efektivitas penerapan sistem informasi akuntansi, pemanfaatan teknologi informasi, kesesuaian tugas, serta keahlian pemakai komputer. Tempat yang akan di teliti yaitu pada PT Karya Luhur Pemai Denpasar sebagai salah satu perusahaan retailer. Berbeda dengan tempat yang diteliti oleh penelitian yang terdahulu yang terdapat pada Koperasi Simpan Pinjam.

Penelitian ini juga merupakan kombinasi dari penelitian yang dilakukan oleh Pratama dan Suardikha (2013) yang berjudul Keahlian Pemakai Komputer dan Kenyamanan Fisik dan Tingkat Efektivitas Sistem Informasi Akuntansi terhadap Kinerja Karyawan yang dilakukan pada sektor perbankan yaitu pada PT. Bank Sinar Harapan Bali Denpasar. Dimana dalam hal ini keahlian pemakai 
Ni Made Fikiyaya Anjani Dewantari dan I Made Pande Dwiana Putra. Pengaruh ...

komputer dan kenyamanan fisik tidak mampu meningkatkan pengaruh tingkat efektivitas penerapan sistem informasi akuntansi terhadap kinerja karyawan di PT Bank Sinar Harapan Bali Denpasar.

Efektivitas berkaitan dengan relevansi suatu informasi dalam mendukung suatu proses bisnis, termasuk di dalamnya harus disajikan dalam waktu yang tepat, akurat, konsisten, dapat digunakan dan lengkap (Azhar Susanto, 2013:13). Informasi yang diterima dengan tepat waktu dapat meningkatkan kualitas pengambilan keputusan. Peningkatan kinerja individu tidak akan tercapai jika penerapan sistem informasi yang tidak sesuai dengan kebutuhan pemakai (Indralesmana dan Suaryana, 2014). Suatu sistem dinilai berjalan secara efektif, apabila mampu memenuhi kebutuhan dan keinginan berbagai pengguna yang ada dalam organisasi baik secara individual maupun kelompok (Rahmi, 2013).

Pengukuran kinerja individual dapat dilihat dari adanya dampak teknologi sistem informasi terhadap efektivitas penyelesaian tugas, membantu meningkatkan kinerja dan menjadikan pemakainya lebih kreatif dan produktif. Efektivitas berpengaruh terhadap kinerja individual melalui penggunaan sistem informasi (Damayanthi dan Sierrawati, 2012).

Penelitian oleh Indralesmana dan Suaryana (2014) serta Astuti dan Dharmadiaksa (2014) menunjukkan bahwa. Hasil tersebut menunjukkan bahwa sistem informasi akuntansi memberi kesempatan untuk meningkatkan efektivitas dan efisiensi dalam pengambilan keputusan sehingga memungkinkan perusahaan memperoleh keunggulan kompetitif, hal ini berarti efektivitas penerapan sistem informasi akuntansi berpengaruh positif dan signifikan terhadap kinerja karyawan. 
Menurut Awosejo et at. (2013) adanya sistem informasi akuntansi dalam sebuah organisasi dapat meningkatkan kinerja individu.

Prajanti (2014), Ocktotawwa (2015) dan Dita dan Putra (2016) juga menyatakan bahwa efektivitas penerapan sistem informasi akuntansi bepengaruh positif dan siginifikan terhadap kinerja karyawan. Hal tersebut dilihat dari sistem informasi akuntansi dapat mempermudah dan mempercepat penyelesaian tugas yang dilakukan setiap individu di lembaga tersebut. Nurwakhida (2016) menyatakan bahwa sistem informasi akuntansi berpengaruh positif dan signifikan terhadap kinerja karyawan. Berdasarkan uraian tersebut dan hasil penelitian terdahulu maka dapat diajukan hipotesis sebagai berikut:

$\mathrm{H}_{1}$ : Efektivitas penerapan sistem informasi akuntansi berpengaruh positif pada kinerja karyawan.

Pemanfaatan teknologi informasi adalah tingkat penerapan pemanfaatan dan penggunaan teknologi informasi yang akan mempengaruhi kinerja individual yaitu sikap kinerja individual terhadap penggunaan komputer. Peningkatan kinerja terjadi ketika individu dapat memenuhi kebutuhan dalam menyelesaikan dan melaksanakan tugasnya (Kinarwanto, 2013). Salamah (2012) menyatakan bahwa pemanfaatan teknologi informasi adalah manfaat yang diharapkan pengguna sistem informasi dalam menjalankan tugas atau perilaku mereka dalam menggunakan teknologi pada saat melakukan pekerjaan.

Beberapa penelitian yang telah dilakukan oleh Ocktotawwa (2015) dan Suyati (2015) menyatakan bahwa kesesuaian tugas berpengaruh positif tehadap kinerja karyawan. Darmini dan Putra (2009) serta Kinarwanto (2013) juga menyatakan bahwa dengan teknologi informasi individu di perusahaan dapat 
Ni Made Fikiyaya Anjani Dewantari dan I Made Pande Dwiana Putra. Pengaruh ...

menghasilkan ouput dan kinerja yang semakin baik, hal ini berarti pemanfaatan teknologi informasi berpengaruh positif dan signifikan terhadap kinerja karyawan di perusahaan. Berdasarkan uraian tersebut dan hasil penelitian terdahulu maka dapat diajukan hipotesis sebagai berikut:

$\mathrm{H}_{2}$ : Pemanfaatan teknologi informasi berpengaruh positif pada kinerja karyawan.

Kesesuaian tugas-teknologi adalah hubungan tugas dengan sistem teknologi informasi yang menunjukkan hubungan antara penggunaan sistem teknologi informasi dengan kebutuhan tugas dalam menyelesaikan suatu pekerjaan (Tanuwijaya, 2013). Kesesuaian tugas berhubungan dengan sejauh mana kemampuan individual menggunakan teknologi informasi dalam menjalankan tugas untuk meningkatkan kinerja individual (Astuti dan Dharmadiaksa, 2014).

Suyati (2015) dan Ocktotawwa (2015) menyatakan bahwa kesesuaian tugas berpengaruh positif tehadap kinerja karyawan. Penelitian yang dilakukan oleh Marlinawati dan Suaryana (2013) serta Tanuwijaya (2013) juga menemukan bahwa kesesuaian tugas dengan teknologi berpengaruh positif dan signifikan terhadap kinerja karyawan. Kesesuaian tugas dengan keahlian penggunaan teknologi informasi akan meningkatkan kemampuan teknis karyawan. Hal tersebut juga dikemukakan oleh Akbar (2018) dimana kesesuaian tugas teknologi berpengaruh positif terhadap kinerja karyawan. Berdasarkan uraian tersebut dan hasil penelitian terdahulu maka dapat diajukan hipotesis sebagai berikut:

$\mathrm{H}_{3}$ : Kesesuaian tugas berpengaruh positif pada kinerja karyawan.

Suatu teknologi komputer dapat diterima tergantung pada teknologi itu sendiri, tingkat skill dan expertise dari individu yang menggunakannya. Aplikasi 
teknologi yang tepat akan mendatangkan competitive advantage bagi perusahaan. Bagi individu, keahlian yang dimiliki akan meningkatkan kinerja individu yang bersangkutan.

Pratama dan Suardikha (2013) menyatakan bahwa keahlian pemakai komputer dapat meningkatkan kinerja indivdual apabila keahlian pemakai komputer meningkat. Karyawan sebagai salah satu pihak yang berhubungan dengan kalangan usahawan, harus terus mengamati setiap perkembangan yang terjadi di dunia bisnis, termasuk berbagai perangkat keras dan lunak yang digunakan untuk mendukung kinerja perusahaan dalam meningkatkan efisiensi dan efektivitas kinerja karyawan (Hidayat, 2013).

Dari beberapa penelitian yang telah dilakukan oleh Suyati (2015), Ocktotawwa (2015) serta Pratama dan Suardikha (2013), menemukan bahwa keahlian pemakai komputer berpengaruh positif dan signifikan tehadap kinerja karyawan. Hal ini menunjukkan adanya hubungan yang kuat antara kemampuan dan keberhasilan implementasi sistem informasi dalam upaya meningkatkan kinerja karyawan. Semakin lihai pengguna atau pemakai komputer maka semakin efektif penerapan sistem informasi yang berpengaruh pada peningkatan kinerja karyawan di perusahaan. Berdasarkan uraian tersebut dan hasil penelitian terdahulu maka dapat diajukan hipotesis sebagai berikut:

$\mathrm{H}_{4}$ : Keahlian pemakai komputer berpengaruh positif pada kinerja karyawan. 
Ni Made Fikiyaya Anjani Dewantari dan I Made Pande Dwiana Putra. Pengaruh ...

\section{METODE PENELITIAN}

Penelitian ini dilakukan pada salah satu perusahaan retailer di Bali yaitu PT. Karya Luhur Permai Denpasar atau yang dikenal dengan sebutan Tiara Dewata yang terletak di Kota Denpasar tepatnya di Jalan Mayjend Sutoyo No. 55 Denpasar. Alasan penelitian ini dilakukan pada PT. Karya Luhur Permai Denpasar adalah karna perusahaan ini adalah salah satu perusahaan retailer tersebsar dan tertua di Bali, yang dimana dalam pengoperasiannya sudah memakai teknologi informasi dan sistem informasi akuntansi. Variabel bebas dalam penelitian ini adalah efektivitas penerapan sistem informasi akuntansi $\left(\mathrm{X}_{1}\right)$, pemanfaatan teknologi informasi $\left(\mathrm{X}_{2}\right)$, kesesuaian tugas $\left(\mathrm{X}_{3}\right)$, dan keahlian pemakai komputer $\left(\mathrm{X}_{4}\right)$. Variabel terikat dalam penelitian ini adalah kinerja karyawan $(\mathrm{Y})$.

Populasi yang digunakan dalam penelitian ini adalah seluruh karyawan pada PT. Karya Luhur Permai Denpasar yang berkaitan langsung dengan penerapan sistem informasi akuntansi serta menggunakan perangkat komputer dalam menjalankan aktivitasnya, yang berjumlah 111 orang. Penentuan sampel dalam penelitian ini dilakukan dengan jenis non probability sampling. Non probability sampling jenis sampel ini tidak dipilih secara acak. Tidak semua unsur atau elemen populasi mempunyai kesempatan sama untuk bisa dipilih menjadi sampel.

Cara mengetahui pengaruh kecerdasan intektual, kecerdasan emosi dan kecerdasan spiritual terhadap kinerja PT. Karya Luhur Permai Denpasar, maka digunakanlah model analisis regresi linear berganda. Persamaan regresinya sebagai berikut:

$Y=\alpha+\beta_{1} X_{1}+\beta_{2} X_{2}+\beta_{3} X_{3}+\beta_{4} X_{4}+e$ 
Keterangan :

$\mathrm{Y}=$ Kinerja karyawan

$\alpha=$ Intercept

$\beta_{1}=$ Koefisien regresi variabel efektivitas penerapan sistem informasi akuntansi

$\beta_{2}=$ Koefisien regresi variabel pemanfaatan

$\beta_{3}=$ Koefisien regresi variabel kesesuaian tugas

$\beta_{4}=$ Koefisien regresi variabel keahlian pemakai komputer

$\mathrm{X}_{1}=$ Efektivitas penerapan sistem informasi akuntansi

$\mathrm{X}_{2}=$ Pemanfaatan teknologi informasi

$\mathrm{X}_{3}=$ Kesesuaian tugas

$\mathrm{X}_{4}=$ Keahlian pemakai komputer

e $=$ Komponen residual atau error term.

\section{HASIL DAN PEMBAHASAN}

Berdasarkan Tabel 1 dapat dilihat bahwa variabel independen yang memiliki nilai rata-rata tertingi yaitu variabel pemanfaatan teknologi informsi dengan nilai 5,23, dan diikuti oleh variabel keahlian pemakai komputer dan kesesuaian tugas yaitu masing-masing sebesar 5,21 dan 5,20. Variabel independen yang memiliki nilai terendah dari seluruh variabel independen yaitu adalah variabel efektivitas penerapan sistem informasi akuntansi dengan nilai rata-rata yaitu 5,08.

Tabel 1.

Uji Statistik Deskriptif

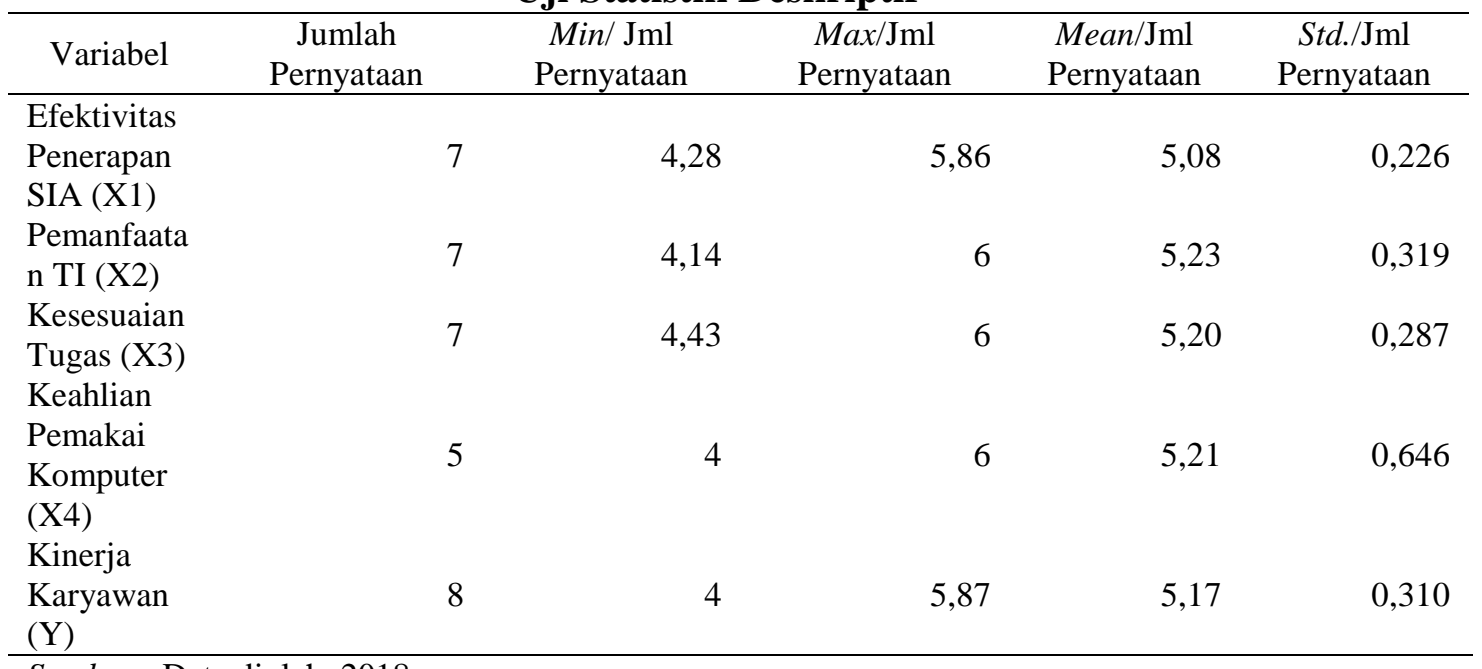

Sumber : Data diolah, 2018 
Ni Made Fikiyaya Anjani Dewantari dan I Made Pande Dwiana Putra. Pengaruh ...

Analisis regresi linier berganda (multiple linear regression) digunakan untuk menguji hipotesis yang ada, yaitu untuk melihat pengaruh efektivitas penerapan sistem informasi akuntansi, pemanfaatan teknologi informasi, kesesuaian tugas, dan keahlian pemakai komputer terhadap kinerja PT. Karya Luhur Permai Denpasar. Hasil dari analisis regresi linear berganda dapat dilihat pada Tabel 2. berikut ini.

Tabel 2.

Hasil Analisis Regresi Linear Berganda

\begin{tabular}{lccc}
\hline Variabel & $\begin{array}{c}\text { Unstandardized } \\
\text { Coefficients }\end{array}$ & $\mathrm{t}$ Hitung & Sig. \\
\hline Efektivitas Penerapan SIA (X1) & 0,237 & 2,350 & 0,021 \\
Pemanfaatan TI (X2) & 0,459 & 5,294 & 0,000 \\
Kesesuaian Tugas (X3) & 0,369 & 4,076 & 0,000 \\
Keahlian Pemakai Komputer (X4) & 0,140 & 2,720 & 0,008 \\
(Constant) & $-0,896$ & $-0,220$ & 0,827 \\
R & 0,726 & & \\
R Square & 0,527 & & \\
Ajusted R Square & 0,509 & & 0,000 \\
F Hitung & 29,551 & & \\
Std. Error of the Estimate & 1,738 & &
\end{tabular}

Sumber: Data diolah, 2018

Berdasarkan Tabel 2 maka didapatkan hasil persamaan sebagai berikut :

$$
Y=-0,896+0,237 X_{1}+0,459 X_{2}+0,369 X_{3}+0,140 X_{4}
$$

Nilai koefisien regresi variabel efektivitas penerapan sistem informasi akuntansi (X1) adalah 0,237 dan menunjukkan efektivitas penerapan sistem informasi akuntansi (X1) bernilai positif, hal ini berarti efektivitas penerapan sistem informasi akuntansi (X1) mempunyai pengaruh positif terhadap kinerja karyawan (Y), artinya jika efektivitas penerapan sistem informasi akuntansi (X1) meningkat satu satuan akan cenderung meningkatkan kinerja karyawan (Y) sebesar 0,237 satuan dengan asumsi variabel lainnya sama dengan nol. 
Nilai koefisien regresi variabel pemanfataan teknologi informasi (X2) adalah 0,459 dan menunjukkan pemanfataan teknologi informasi (X2) bernilai positif, hal ini berarti pemanfataan teknologi informasi (X2) mempunyai pengaruh positif terhadap kinerja karyawan (Y), artinya jika pemanfataan teknologi informasi (X2) meningkat satu satuan akan cenderung meningkatkan kinerja karyawan (Y) sebesar 0,459 satuan dengan asumsi variabel lainnya sama dengan nol.

Nilai koefisien regresi variabel kesesuaian tugas (X3) adalah 0,369 dan menunjukkan kesesuaian tugas (X3) bernilai positif, hal ini berarti kesesuaian tugas (X3) mempunyai pengaruh positif terhadap kinerja karyawan (Y), artinya jika kesesuaian tugas (X3) meningkat satu satuan akan cenderung meningkatkan kinerja karyawan (Y) sebesar 0,369 satuan dengan asumsi variabel lainnya sama dengan nol.

Nilai koefisien regresi variabel keahlian pemakai komputer (X4) adalah 0,140 dan menunjukkan keahlian pemakai komputer (X4) bernilai positif, hal ini berarti keahlian pemakai komputer (X4) mempunyai pengaruh positif terhadap kinerja karyawan (Y), artinya jika keahlian pemakai komputer (X4) meningkat satu satuan akan cenderung meningkatkan kinerja karyawan (Y) sebesar 0,140 satuan dengan asumsi variabel lainnya sama dengan nol.

Analisis determinasi digunakan sebagai alat untuk mengetahui besarnya persentase hubungan atau pengaruh variabel independen (efektivitas penerapan sistem informasi akuntansi, pemanfataan teknologi informasi, kesesuaian tugas, dan keahlian pemakai komputer) terhadap variabel dependen (kinerja karyawan), 
Ni Made Fikiyaya Anjani Dewantari dan I Made Pande Dwiana Putra. Pengaruh ...

yang dinyatakan dalam persentase. Berdasarkan data pada Tabel 2 diperoleh angka $\mathrm{R}^{2}$ sebesar 0,527 atau $52,7 \%$. Hal ini menunjukkan bahwa 52,7\% variabel dependen (kinerja karyawan) dipengaruhi oleh variabel independen (efektivitas penerapan sistem informasi akuntansi, pemanfataan teknologi informasi, kesesuaian tugas, dan keahlian pemakai komputer), sedangkan sisanya sebesar 47,3\% dipengaruhi atau dijelaskan oleh variabel lain yang tidak dimasukkan dalam penelitian ini.

Uji kelayakan model bertujuan untuk mengetahui apakah model regresi layak digunakan dengan menggunakan uji simultan (uji F). Pengujian dilakukan dengan menggunakan tingkat keyakinan 95\% dengan taraf kesalahan $(\alpha)$ yang digunakan yaitu 5\% atau $0,05(\alpha=5 \%)$. Ketentuan model regresi dinyatakan layak apabila signifikasi $\mathrm{F}_{\text {hitung }}<\alpha(0,05)$.

Berdasarkan Tabel 2 menunjukkan bahwa nilai signifikan kurang dari 0,05 $(0,000<0,05)$, hal ini menunjukkan bahwa model regresi dengan variabel independen yaitu efektivitas penerapan sistem informasi akuntansi, pemanfaatan teknologi informasi, kesesuaian tugas, dan keahlian pemakai komputer dan variabel dependen yaitu kinerja karyawan layak untuk digunakan.

Uji hipotesis digunakan untuk menguji seberapa jauh pengaruh satu variabel independen secara individual dalam menerangkan variabel dependen. Cara untuk mengetahui hasil uji hipotesis adalah dengan melihat hasil regresi yang dilakukan dengan program SPSS, yaitu dengan melihat nilai t hitung, membandingkat tingkat signifikansi variabel bebas dengan $\alpha=0,05$ atau 5\%, dan membandingkan nilai $\beta$. 
Berdasarkan Tabel 2 dapat dilihat bahwa variabel efektivitas penerapan sistem teknologi akuntansi memiliki nilai $\beta_{1}$ positif lebih besar daripada nol sebesar 0,237 dengan nilai signifikansi lebih kecil dari 0,05 sebesar 0,021. Nilai tersebut menunjukkan $\mathrm{H}_{1}$ diterima, yang artinya efektivitas penerapan sistem infomasi akuntansi berpengaruh positif dan signifikan terhadap kinerja karyawan.

Variabel pemanfaatan teknologi informasi memiliki nilai $\beta_{2}$ positif lebih besar daripada nol sebesar 0,459 dengan nilai signifikansi lebih kecil dari 0,05 sebesar 0,000 . Nilai tersebut menunjukkan $\mathrm{H}_{2}$ diterima, yang artinya pemanfaatan teknologi informasi berpengaruh positif dan signifikan terhadap kinerja karyawan.

Variabel kesesuaian tugas memiliki nilai $\beta_{3}$ positif lebih besar daripada nol sebesar 0,369 dengan nilai signifikansi lebih kecil dari 0,05 sebesar 0,000. Nilai tersebut menunjukkan bahwa $\mathrm{H}_{3}$ diterima, yang artinya kesesuaian tugas berpengaruh positif dan signifikan terhadap kinerja karyawan.

Variabel keahlian pemakai komputer memiliki nilai $\beta_{4}$ positif lebih besar daripada nol sebesar 0,140 dengan nilai signifikansi lebih kecil dari 0,05 sebesar 0,008. Nilai tersebut menujukan bahwa $\mathrm{H}_{4}$ diterima, yang artinya keahlian pemakai komputer berpengaruh positif dan signifikan terhadap kinerja karyawan.

Hasil penelitian menunjukkan bahwa hipotesis pertama dalam penelitian ini diterima. Artinya bahwa efektivitas penerapan sistem informasi akuntansi berpengaruh positif pada kinerja karyawan. Pengaruh positif tersebut berarti semakin tinggi efektivitas penerapan sistem informasi akuntansi, maka semakin tinggi kinerja karyawan. Pengaruh sistem informasi akuntansi yang efektif dan mudah digunakan dapat membantu karyawan. Sistem informasi akuntansi yang 
Ni Made Fikiyaya Anjani Dewantari dan I Made Pande Dwiana Putra. Pengaruh ...

efektif dapat mempermudah dan mempercepat penyelesaian tugas yang dilakukan setiap karyawan. Hasil penelitian ini mendukung teori TAM yang dimana menyebutkan bahwa pengguna sistem cenderung menggunakan sistem apabila sistem mudah digunakan dan bermanfaat bagi pengguna sistem tersebut. Thompson et al., (1994) menyatakan bahwa individu akan menggunakan sistem jika mengetahui kegunaan atau manfaat positif dari penggunaan sistem tersebut.

Hal ini didukung dengan penelitian terdahulu oleh Prajanti (2014), Ocktotawwa (2015) dan Dita dan Putra (2016) juga menyatakan bahwa efektivitas penerapan sistem informasi akuntansi bepengaruh positif dan siginifikan terhadap kinerja karyawan. Nurwakhida (2016) juga menyatakan bahwa sistem informasi akuntansi berpengaruh positif dan signifikan terhadap kinerja karyawan.

Nilai pernyataan tertinggi menyebutkan bahwa sistem informasi akuntansi dalam perusahaan sangat mudah digunakan. Hal ini berarti pemahaman karyawan dalam menggunakan sistem informasi akuntansi yang terdapat dalam perusahaan sudah sangat membantu karyawan tersebut, sehingga dapat meningkatkan kinerja karyawan dalam perusahaan.

Efektivitas penerapan sistem informasi ternyata memiliki nilai mean dan nilai Beta paling kecil diantara variabel independen lainnya. Hal ini berarti efektivitas penerapan sistem informasi akuntansi masih perlu diperbaiki dengan sistem yang nantinya akan menyajikan informasi yang lebih efektif untuk mendukung proses pengambilan keputusan yang akan dibuat. Nilai tersebut juga dapat disebabkan dari adanya karyawan yang memiliki tingkat pendidikan yang dominan hanya lulusan SMA/sederajat dan masa kerja dominan kurang dari lima 
tahun sehingga perusahaan perlu adanya pelatihan-pelatihan kembali untuk karyawan yang menggunakan sistem informasi akuntansi pada perusahaan.

Hasil penelitian menunjukkan bahwa hipotesis kedua dalam penelitian ini diterima. Artinya bahwa pemanfaatan teknologi informasi berpengaruh positif pada kinerja karyawan. Pengaruh positif tersebut berarti semakin tinggi pemanfaatan teknologi informasi, maka semakin tinggi kinerja karyawan. Pemanfaatan teknologi informasi yang tepat dan didukung oleh keahlian personil dalam mengoperasikannya dapat meningkatkan kinerja individu maupun perusahaan yang bersangkutan Darmini dan Putra (2009). Dengan adanya teknologi informasi, individu yang merupakan pemakai sistem tersebut akan menghasilkan output yang semakin baik dan kinerja yang akan meningkat Siregar dan Suryanawa (2009). Hasil penelitian ini mendukung teori TAM khususnya usefulness yaitu seseorang merasa yakin bahwa dengan menggunakan sistem tersebut akan meningkatkan kinerja pekerjaannya. Teori TAM meyakini bahwa penggunaan sistem informasi akan memberikan manfaat kepada individu atau organisasi dan penggunaan sistem informasi akan mempermudah pemakainya dalam menyelesaikan suatu pekerjaan (Gupta et al., 2007).

Hal ini didukung dengan penelitian terdahulu oleh Ocktotawwa (2015) dan Suyati (2015) menyatakan bahwa kesesuaian tugas berpengaruh positif tehadap kinerja karyawan. Darmini dan Putra (2009) juga menyatakan bahwa pemanfaatan teknologi informasi berpengaruh positif dan signifikan terhadap kinerja karyawan di dalam perusahaan. 
Ni Made Fikiyaya Anjani Dewantari dan I Made Pande Dwiana Putra. Pengaruh ...

Pemanfaatan teknologi informasi memiliki nilai mean dan nilai Beta paling besar diantara variabel independen lainnya. Hal ini berarti pemanfaatan teknologi informasi menjadi variabel paling dominan diantara variabel independen lainnya, yang artinya pemanfaatan teknologi informasi di perusahaan ini sudah sangat membantu kinerja karyawan, terutama dalam kelengkapan perangkat lunak yang telah disediakan oleh perusahaan. Namun, perusahaan harus tetap memperbaiki komputer yang ada agar mempercepat proses pekerjaan karyawan.

Hasil penelitian menunjukkan bahwa hipotesis ketiga dalam penelitian ini diterima. Artinya bahwa kesesuaian tugas berpengaruh positif pada kinerja karyawan. Pengaruh positif tersebut berarti semakin sesuaian tugas dengan teknologi yang ada, maka semakin tinggi kinerja karyawan. Meningkatkan kinerja dapat dilakukan dengan cara mengevaluasi pemakai atas kecocokan tugas dengan teknologi yang artinya berkaitan dengan pencapaian kinerja karyawan yang tinggi. Hasil penelitian ini mendukung teori TPC, yang menyebutkan bahwa teknologi yang berdampak positif terhadap kinerja berarti teknologi tersebut harus digunakan dan sesuai dengan tugas-tugas yang mendukungnya.

Hal ini didukung dengan penelitian terdahulu oleh Suyati (2015) dan Ocktotawwa (2015) menyatakan bahwa kesesuaian tugas berpengaruh positif tehadap kinerja karyawan. Penelitian yang dilakukan oleh Marlinawati dan Suaryana (2013) serta (Tanuwijaya, 2013) juga menyatakan bahwa kesesuaian tugas dengan teknologi berpengaruh positif dan signifikan terhadap kinerja karyawan. Hal tersebut juga dikemukakan oleh Akbar (2018). 
Nilai pernyataan tertinggi menyebutkan bahwa dengan adanya kesesuaian informasi yang ditampilkan dari suatu sistem menjadikan kinerja tidak terhambat dan membantu dalam memberikan kesesusian data. Hal ini berarti teknologi yang terdapat dalam perusahaan sudah membantu dalam kesesuaian tugas karyawan, sehingga dapat meningkatkan kinerja karyawan dalam perusahaan. Meskipun demikian, perusahaan masih perlu meningkatkan teknologi informasi yang ada guna untuk lebih membantu menyelesaikan tugas tepat pada waktunya.

Hasil penelitian menunjukkan bahwa hipotesis keempat dalam penelitian ini diterima. Artinya bahwa keahlian pemakai komputer berpengaruh positif pada kinerja karyawan. Pengaruh positif tersebut berarti ahli dalam menggunakan komputer, maka semakin tinggi kinerja karyawan. Hal ini menunjukkan adanya hubungan yang kuat antara kemampuan dan keberhasilan implementasi sistem informasi dalam upaya meningkatkan kinerja karyawan. Semakin lihai pengguna atau pemakai komputer maka semakin efektif penerapan sistem informasi yang berpengaruh pada peningkatan kinerja karyawan di perusahaan. Hasil penelitian ini mendukung teori kontigensi, dimana teori ini menyebutkan bahwa variabelvariabel kontigensi yang digunakan dalam mendesain sistem informasi akuntansi harus sesuai dan mudah dipelajari, sehingga dapat membatu pemakaian sistem tersebut sehingga kinerja akan meningkat.

Hal ini didukung dengan penelitian terdahulu oleh Suyati (2015), Ocktotawwa (2015) serta Pratama dan Suardikha (2013), menemukan bahwa keahlian pemakai komputer berpengaruh positif dan signifikan tehadap kinerja karyawan. 
Ni Made Fikiyaya Anjani Dewantari dan I Made Pande Dwiana Putra. Pengaruh ...

Nilai pernyataan tertinggi menyebutkan bahwa karyawan yang terdapat dalam PT Karya Luhur Permai Denpasar memiliki pengetahuan dan kemampuan menjalankan komputer dengan sangat baik. Hal ini berarti karyawan tersebut sudah memiliki keahlian dalam menggunakan komputer sehingga membantu dalam menyelesaikan tugas yang diberikan dan dapat meningkatkan kinerja karyawan dalam perusahaan. Namun, perusahaan harus terus memberikan pelatihan agar setiap karyawan dapat menggunakan teknologi informasi dengan lebih cepat dan lebih baik.

Hasil penelitian ini diharapkan mampu memberikan gambaran serta wawasan yang lebih luas dalam bidang penerapan sistem informasi akuntansi dan memperoleh pemahaman yang lebih baik tentang Techology Acceptance Model (TAM) dan Teori Technologi-to-Perfomance Chain (TPC). Penelitian ini telah membuktikan bahwa efektivitas penerapan sistem informasi akuntansi, pemanfataan teknologi, kesesuaian tugas dan keahlian pemakai komputer mempunyai pengaruh positif terhadap kinerja karyawan, sehingga sangat mendukung konsep dari TAM dan Teori TPC.

Hasil penelitian ini diharapkan mampu memberikan referensi, masukan dan tambahan informasi bagi perusahaan dalam mengambil keputusan implementasi dan pengembangan sistem informasi akuntansi perusahaan di masa yang akan datang sehingga nantinya dapat meningkatkan kinerja karyawan yang terdapat dalam PT Karya Luhur Permai Denpasar. 


\section{SIMPULAN}

Hipotesis pertama dalam penelitian ini diterima. Artinya bahwa efektivitas penerapan sistem informasi akuntansi berpengaruh positif pada kinerja karyawan. Pengaruh positif tersebut berarti semakin tinggi efektivitas penerapan sistem informasi akuntansi, maka semakin tinggi kinerja karyawan.

Hipotesis kedua dalam penelitian ini diterima. Artinya bahwa pemanfaatan teknologi informasi berpengaruh positif pada kinerja karyawan. Pengaruh positif tersebut berarti semakin tinggi pemanfaatan teknologi informasi, maka semakin tinggi kinerja karyawan.

Hipotesis ketiga dalam penelitian ini diterima. Artinya bahwa kesesuaian tugas berpengaruh positif pada kinerja karyawan. Pengaruh positif tersebut berarti semakin sesuaian tugas dengan teknologi yang ada, maka semakin tinggi kinerja karyawan.

Hasil penelitian menunjukkan bahwa hipotesis keempat dalam penelitian ini diterima. Artinya bahwa keahlian pemakai komputer berpengaruh positif pada kinerja karyawan. Pengaruh positif tersebut berarti ahli dalam menggunakan komputer, maka semakin tinggi kinerja karyawan.

Dari empat variabel independen yang berpengaruh terhadap kinerja karyawan, variabel yang dominan adalah pemanfaatan teknologi informasi. Berdasarkan hasil analisis regresi linear berganda, dapat dijelaskan bahwa $\beta_{2}$ memiliki nilai paling tertinggi.

Berkaitan dengan efektivitas sistem informasi akuntansi, sebaiknya sistem informasi akuntansi pada PT Karya Luhur Permai Denpasar penerapannya lebih 
Ni Made Fikiyaya Anjani Dewantari dan I Made Pande Dwiana Putra. Pengaruh ...

diefektifkan, sebab melalui sistem, informasi disajikan lebih cepat sehingga berguna di dalam mendukung proses pengambilan keputusan.

Berkaitan dengan pemanfaatan teknologi informasi, sebaiknya manajemen PT Karya Luhur Permai Denpasar lebih meningkatan pemanfaatan teknologi informasi yang berbasis komputerisasi, sebab peranan maupun fungsi komputerisasi yang diterapkan oleh perusahaan dapat mempercepat proses pekerjaan pada PT Karya Luhur Permai Denpasar.

Berkaitan dengan kesesuaian tugas-teknologi, manajemen PT Karya Luhur Permai Denpasar hendaknya lebih memperhatikan kesesuaian tugas karyawan dengan kemampuan individual dalam menggunakan teknologi informasi, sehingga dapat meningkatkan kinerja individual dalam melaksanakan tugas.

Berkaitan dengan keahlian pemakai komputer, hendaknya manajemen PT Karya Luhur Permai Denpasar lebih banyak mengikutkan karyawan dalam setiap pelatihan-pelatihan maupun kursus yang berkaitan akuntansi dan komputer. Diharapkan nantinya setiap karyawan memiliki kemampuan dalam menyelesaikan tugas yang lebih baik dan lebih cepat dengan menggunakan komputer dan sistem informasi akuntansi.

\section{REFERENSI}

Akbar, A. M. (2018). Kemampuan, Kepercayaan, Kesesuaian Tugas-Teknologi dan Pemanfaatan Teknologi Informasi terhadap Kinerja Karyawan (Studi Empiris pada Karyawan Administrasi Universitas Muhammadiyah Surakarta). Skripsi. Surakarta : Fakultas Ekonomi dan Bisnis Universitas Muhammadiyah Surakarta

Alsarayreh M.N., Jawabreh O.A., Jaradat M.F., and Alamro S.A. (2011). Technological Impact of Effectiveness of Accounting Information System 
(AIS) Applied by Aqaba Tourist Hotels. European Journal of Scientific Research, 59(3), 361-369.

Asiyatun. (2012). Pengaruh Kesesuaian Tugas-Teknologi, Keahlian Pengguna, dan Pemanfaatan Teknologi Informasi Terhadap Kinerja Karyawan di Bpd Jawa Tengah Kantor Cabang Surakarta. Skripsi. Surakarta : Jurusan Akuntansi Fakultas Ekonomi Universitas Muhammadiyah Surakarta.

Astuti, N.M.M.P. dan Dharmadiaksa, I.B. (2014). Pengaruh Efektivitas Penerapan Sistem Informasi Akuntansi, Pemanfaatan dan Kesesuaian Tugas pada Kinerja Karyawan. E-Jurnal Akuntansi Universitas Udayana, 9(2), 373384.

Awosejo, O.J, dkk. (2013). The Effect of Accounting Information Systems in Accounting. Internasional Journal of Advanced Computer Research, ISSN : 2277-7970, 3 .

Bailey, J. E. and S. W. P. (1983). Development of a Tool For Measuring and Analyzing Computer User Satisfaction. Management Science, 29(5), 530545.

Damayanthi, IGA, E. dan Sierrawati, N. L. M. (2012). Pengaruh Efektivitas Sistem Informasi Akuntansi dan Penggunaan Teknologi Informasi terhadap Kinerja Individual pada Koperasi Simpan Pinjam di Kecamatan Denpasar Barat. Jurnal Riset Akuntansi, 2(1), 23-43.

Darmini, A. A. S. R. dan P. I. N. W.A. (2009). Pemanfaatan Teknologi Informasi dan Pengaruhnya terhadap Kinerja Individual pada Bank Perkreditan Rakyat di Kabupaten Tabanan. Jurnal Jurusan Akuntansi, 4(1).

Davista, D. Y. (2008). Pengaruh Kesesuaian Tugas-Teknologi, Keahlian Pengguna, dan Pemanfaatan Teknologi Informasi Terhadap Kinerja Karyawan (Survey Pada Karyawan Bank Bagian Akutansi Dikota Surakarta). Skripsi. Surakarta : Ums.

Dita, Ambara dan Putra, I Wayan. (2016). Pengaruh Penerapan Sistem Informasi Akuntansi Terhadap Kinerja Karyawan Dengan Integritas Karyawan Sebagai Variabel Pemoderasi. E-Jurnal Akuntansi Universitas Udayana, 15(1), 614-640.

Gupta M.P, Kanungo S, Kumar R. and Sahu G.P. (2007). A Study of Information Technology Efectiveness in Select Government Organizations in India. Journal for Decision Makers, 32(2).

Hidayat, S.R. (2013). Pengaruh Keahlian Pengguna, Kepercayaan, Pemanfaatan dan Kesesuaian Tugas dalam Informasi terhadap Kinerja Individu. Skripsi. 
Ni Made Fikiyaya Anjani Dewantari dan I Made Pande Dwiana Putra. Pengaruh ...

Surakarta : Universitas Muhammadiyah Surakarta.

Hidayati, Laili. (2017). Pengaruh Efektivitas Pemanfaatan Sistem Informasi Akuntansi, Keahlian Pemakai dan Lingkungan Pengendalian Terhadap Kinerja Pegawai Bank Syariah Mandiri Kcp Ambarukmo Yogyakarta. Skripsi. Yogyakarta : Fakultas Ekonomi Dan Bisnis Islam Universitas Islam Negeri Sunan Kalijaga Yogyakarta

Indralesmana, K.W. dan Suaryana, I. G. N.A. (2014). Penerapan Sistem Informasi Akuntansi dan Kinerja Individu Pada Usaha Kecil dan Menengah di Nusa Penida. Jurnal Akuntansi, 7(2), 345-356.

Ismail, N. A, and King Malcolm. (2007). Factors Influencing The Alignment of Accounting Information Systems in Small and Medium Sized Malaysian Manufacturing Firms. Journal of Information Systems and Small Business, 1(1), 1-20.

Jong Min Choe. (1996). The Relationship Among Performance of Accounting Information System, Influence Factor and Evolution Level of Information System. Journal of Management Information System, 12(4), 215-239.

Jurnali, T. dan Bambang Supomo. (2002). Pengaruh Faktor Kesesuaian Tugas Teknologi dan Pemanfaatan Teknologi Informasi Terhadap Kinerja Akuntan Publik. Jurnal Riset Akuntansi Indonesia, 5(2), 66-77.

Kasandra, N. M. A. A. (2014). Pengaruh Kualitas Penerapan Sistem Informasi Akuntansi, Pemanfaatan dan Kepercayaan Teknologi Informasi Terhadap Kinerja Karyawan pada Bank Perkreditan Rakyat di Kabupaten Tabanan. Skripsi. Denpasar : Jurusan Akuntansi Fakultas Ekonomi dan Bisnis Universitas Udayana.

Kharuddin, S., Nassir, M.A., and M. Z. Ashhari. (2010). Information System and Firms Performance: The Case of Malaysian Small Medium Enterprise. International Bussinessresearch, 3(4), 33.

Kinarwanto, Bangun. (2013). Faktor-faktor Pemanfaatan Teknologi Informasi dan Pengaruhnya terhadap Kinerja Individual. Jurnal Ilmiah Mahasiswa FEB, 1(2), 210-231.

Kouser, R., Awan, Shahzad, F.,and A., Rana, G. (2011). Firm Size, Leverage and Profitability: Overriding Impact of Accounting Information System. Journal of Management and Bussiness Review, 1(10), 58-64.

Marlinawati, N.M.A. dan Suaryana, I. G. N. . (2013). Pengaruh Penggunaan Teknologi Informasi, Efektivitas Sistem Informasi Akuntansi, Kepercayaan Atas Sistem Informasi Akuntansi, dan Kesesuaian Tugas pada Kinerja 
Karyawan Lembaga Perkreditan Desa di Kabupaten Badung. Jurnal Akuntansi, 2(2), 388-401.

Mercika, Ni Luh Dewi Trisna. (2015). Kemudahan Penggunaan Sistem sebagai Pemoderasi Pengaruh Efektivitas Sistem Informasi Akuntansi Terhadap Kinerja Karyawan PT BPR Sri Artha Lestari Denpasar. Skripsi. Denpasar : Jurusan Akuntansi Fakultas Ekonomi dan Bisnis Universitas Udayana.

Nurwakhida, Arnisri Mardikawati. (2016). Pengaruh Efektivitas Penerapan Sistem Informasi Akuntansi Dan Motivasi Terhadap Kinerja Karyawan (Studi Kasus Pada Bprs Bangun Drajat Warga). Skripsi. Yogyakarta : Fakultas Ekonomi Dan Bisnis Islam Universitas Islam Negeri Sunan Kalijaga

Ocktotawwa, A. T. (2015). Pengaruh Efektivitas Penerapan Sistem Informasi Akuntansi, Pemanfaatan, Kesesuaian Tugas, Dan Keahlian Pemakai Komputer Terhadap Kinerja Karyawan. Skripsi. Bandung: Program Studi Akuntansi Fakultas Ekonomi Universitas Pasundan.

Prabowo, Galang Rahadian., Mahmud, Amir. dan Henny Murtini. (2014). FaktorFaktor yang Mempengaruhi Kinerja Sistem Informasi Akuntansi (Studi Kasus Pada Lingkungan Pemerintah Kabupaten Temanggung. Accounting Analysis Journal, 3(1), 9-17.

Prajanti, Eny, Kartika Hendra, dan Siti Nurlela. (2014). Pengaruh Sistem Informasi Akuntansi, Gaya Kepemimpinan dan Kompleksitas Tugas Terhadap Kinerja Karyawan. Jurnal Paradigma, 12(1), 57-70.

Pratama, G.A.P. dan Suardikha, I. M.S. (2013). Keahlian Pemakai Komputer dan Kenyamanan Fisik dan Tingkat Efektivitas Sistem Informasi Akuntansi terhadap Kinerja Karyawan. Jurnal Akuntansi, 5(2), 361-381.

Rahmawati, Diana. (2008). Analisis Faktor-Faktor yang Berpengaruh terhadap Pemanfaatan Teknologi Informasi. Jurnal Ekonomi Dan Pendidikan, 5(1), $107-118$.

Rahmi, Mardia. (2013). Pengaruh Penggunaan Teknologi Informasi dan Keahlian Pemakai terhadap Kualitas informasi Akuntansi. Jurnal Fakultas Ekonomi, $1(2)$.

Raupeliene, A. (2003). Development of A Model For Evaluating The Effectiveness of Accounting Information Systems. Journal of Lithuanian University, 339-345.

Salamah, I. (2012). Utilization Of IT and The Effect On Individual Performance Of Lecturersat State Polytechnic Sriwijaya. Journal of Ecomonics, Business, and Accountancy Ventura, 15(1). 
Ni Made Fikiyaya Anjani Dewantari dan I Made Pande Dwiana Putra. Pengaruh ...

Salehi, Mahdi, Rostami, Vahab, and Abdolkarim Mogadam. (2010). Usefulness of Accounting Information System in Emeriging Economy: Empirical Evidence of Iran. International Journal of Economics and Finance, 2(2), 186-195.

Siregar, A.H. dan Suryanawa, I.K. (2009). Pemanfaatan Teknologi Informasi dan Pengaruhnya terhadap Kinerja Individual pada Kantor Pelayanan Pajak Pratama Denpasar Barat. Jurnal Jurusan Akuntansi, 4(2).

Soudani, Simak Nejadhosseini. (2012). The Usefulness of an Accounting Information System for Effective Organizational Performance. International Journal of Economics and Finance.

Susanto, A. (2013). Sistem Informasi Akuntansi, -Struktur -Pengendalian Resiko-Pengembangan, Edisi Perdana, Cetakan Pertama. Bandung : Lingga Jaya.

Suyati. (2015). Pengaruh Efektivitas Penerapan Sistem Informasi Keuangan, Partisipasi Manajemen, Pemanfaatan Teknologi Informasi, Kesesuaian Tugas Dan Keahlian Pemakai Komputer Terhadap Kinerja Karyawan (Studi Pada Karyawan UMS Dan UNS). Skripsi. Surakarta : Fakultas Ekonomi dan Bisnis Universitas Muhammadiyah Surakarta.

Tanuwijaya, Haryanto. (2013). Pengaruh Faktor Kompleksitas, dan Kesesuaian Tugas-Teknologi terhadap Kinerja Manajerial Melalui Tingkat Pemanfaatan Sistem Informasi. Jurnal Jurusan Sistem Informasi, OSIT(1).

Thompson, R.L., Higgins, christopher A., dan Howwel, Jane M. (1994). Influence of Experience on Personal Computer Utilization: Testing A Conceptual Model. Journal of Management Information Systems, 11(1), 167-187.

Tjhai Fung Jin. (2003). Analisis Faktor-faktor yang Mempengaruhi Pemanfaatan Teknologi Informasi dan Pengaruh Pemanfaatan Teknologi Informasi terhadap Kinerja Akuntan Publik. Jurnal Bisnis Dan Akuntansi, 5(1), 1-26.

Urquia, Grande E., Munoz, Columbia C., and Estebanez, Raquel P. (2010). The Impact of Accounting Information System (AIS) on Performance Measures: Empiricial Evidencein Spanish SMEs1. The International Journal of Digital Accounting Research, 1(1), 25-4.

Wahyuni, Ika. (2014). Faktor-faktor PemanfaatanTeknologi Informasi dan Pengaruhnya Terhadap Kinerja para Pemakai Enterprise Resource Planning (ERP) di PT Semen Tonasa. Tesis. Magister Manajemen. Program Pasca Sarjana Universitas Kristen Satya Wacana Salatiga 
Weyai, M. S. (2012). Kesesuaian Tugas dengan Teknologi dan Utilisasi Terhadap Kinerja Karyawan. 